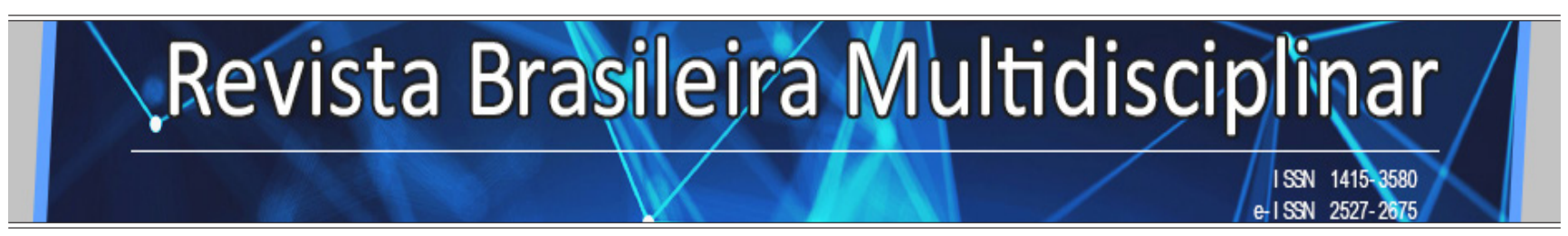

http://revistarebram.com/index.php/revistauniara

\title{
POLYLACTIC ACID SCAFFOLDS OBTAINED BY 3D PRINTING AND MODIFIED BY OXYGEN PLASMA
}

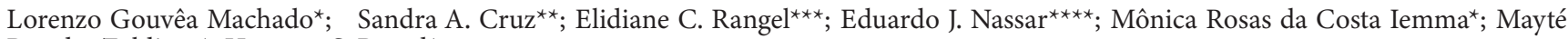
Paredes Zaldivar*; Hernane S. Barud*

* Biopolymers and Biomaterials Research Group - BIOPOLMAT. University of Araraquara - UNIARA. Araraquara, São Paulo, Brazil.

** Department of Chemistry, Center for Exact Sciences and Technology. Federal University of São Carlos - UFSCAR. São Carlos, São Paulo, Brazil.

***Plasma and Materials Group, Sorocaba Institute of Science and Technology. Paulista State University- UNESP. Sorocaba, São Paulo, Brazil.

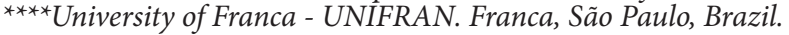

*Autor para correspondência e-mail: hernane.barud@gmail.com

\section{Palavras-chave}

Àcido Polilático (Pla)

Manufatura Aditiva

Plasma De Oxigênio

\section{KEYWORDS}

PLA (Polylactic Acid)

Additive Manufacturing

Oxygen Plasma
The purpose of tissue engineering is to repair, replace, and regenerate tissues and organs. For this aim, materials support, as polylactic acid (PLA), is used. PLA is a thermoplastic polymer that presents biodegradability, biocompatibility and good processability. PLA scaffolds can accurately be constructed by additive manufacturing. Then, the objectives of this work were to modify the hydrophobic surface of PLA scaffolds using oxygen plasma and to study the cell viability and proliferation. The characterization was done by AFM, contact angle, FTIR and studies of proliferation and cell viability. Results showed that the material acquired hydrophilic properties by the presence of oxygen reactive species and by contact angle decrease. It was also observed an increase in the surface roughness. We can conclude that, although the surface modifications were effective and the PLA scaffolds were not cytotoxic, there were no improvements in the proliferation process with the studied osteo-1 lineage cells.

\section{RESUMO}

SCAFFolds de Poliácido LÁtico obTidos Por impress Ão 3 D E FUNCIONALIZAdos POR PLASMA DE OXIGÊNIO

O objetivo da engenharia de tecidos é reparar, substituir e regenerar tecidos e órgãos. Para esse objetivo, são utilizados materiais, como o ácido polilático (PLA). O PLA é um polímero termoplástico que apresenta biodegradabilidade, biocompatibilidade e boa processabilidade. Os scaffolds de PLA podem ser construídos com precisão pela manufatura aditiva. Em seguida, os objetivos deste trabalho foram modificar a superfície hidrofóbica dos scaffolds de PLA usando plasma de oxigênio e estudar a viabilidade e proliferação celular. A caracterização foi realizada por AFM, ângulo de contato, FTIR e estudos de proliferação e viabilidade celular. Os resultados mostraram que o material adquiriu propriedades hidrofílicas pela presença de espécies reativas ao oxigênio e pela diminuição do ângulo de contato. Também foi observado um aumento na rugosidade da superfície. Podemos concluir que, embora as modificações superficiais tenham sido eficazes e os scaffolds do PLA não tenham sido citotóxicos, não houve melhorias no processo de proliferação com as células da linhagem osteo-1 estudadas. 


\section{INTRODUCTION}

Tissue engineering has frequently used polymers as a support for tissue regeneration. Moreover, for the creation of these biological supports (scaffolds), conventional techniques are used, such as fiber-bonding, solvent casting, particulate leaching, membrane lamination, melt molding, thermally induced phase separation and gas foaming. None of these conventional techniques has allowed tissue engineering to reconstruct scaffolds that mimic the extra cellular environment. However, the additive manufacturing has been in the process of being developed to meet the demand for printing complex, high volume structures with good resolution and accuracy, reducing defects and improving mechanical properties (ZEIN, 2002). It is possible to create biological supports (scaffolds) in any scale and quantity, which will tend to the personalized the needs of each patient. For this reason, scaffolds should be biocompatible, versatile and accurate in the reconstruction of diseased or lost tissues. Biofabrication, additive manufacturing and/ or rapid prototyping use the CAD (Computer Aided - Design) system. The additive manufacturing has the three-dimensional printing types: bioprinting (BI), inkjet printing (IP), laser assisted bioprinting (LAB), stereolitography (STL) and fused deposition modeling (FDM) (Bandyopadhyay, 2015). Among the various forms of three-dimensional printing there is rapid prototyping with thermoplastic filament at room temperature, with controlled extrusion and layer-layer construction (LI et al., 2015). The FDMtype additive manufacturing is a rapid prototyping (extruder), in which it is possible to obtain scaffolds with polymers that optimize tissue regeneration techniques, because of their precision of adaptation to the defect or wound to be regenerated(KODAMA, 1981; LU; MIKOS, 1996; NGO et al., 2018)

Among the synthetic polymers, there is a group that presents good properties to biomedical applications: aliphatic polyesters. These polyesters are thermoplastics and hydrolysables, important properties that validate its application as biomaterial in extensive reconstruction and to biomodulation by the host (BRAGHIROLLI, 2012; CHEN et al., 2010). The polylactic acid (PLA) is one member of this family. The PLA filaments present good advantages such as low toxicity, processability, low environmental impact, thermal stability and the possibility of bearing load. These properties make PLA a versatile material for application in tissue engineering as scaffold, for example it can be customized to repair bone defects (MORENT et al., 2011; Bose and Amit, 2012). The scaffold construction by FDM does not use solvents, so a multitude of materials can be constructed by printing PLA filaments (LU; MIKOS, 1996; NGO et al., 2018).

One of the PLA limitations is related to its hydrophobicity. This leads to a lack of cell recognition signals (YEH et al., 2015). Therefore, strategies for modifying the scaffold surface can be achieved by adding functional groups, changing the surface and morphology and removing undesirable components from the biomaterial. The surface modification can be done by plasma treatment by the insertion of new functional groups as well as by changes in the topography. The main advantage of plasma treatment is to modify the surface (at nanometer scale), without changing the material properties (MORENT et al.,2011).

\section{OBJECTIVE}

Thus, the objectives of this work were to modify the hydrophobic surface of 3D printed PLA scaffolds through oxygen plasma and to study the cell viability and proliferation.

\section{METHODOLOGY}

\section{SCAFFOLD CONSTRUCTION}

The scaffolds were modeled in the Autodesk Inventor CAD software, exported in STL format and printed via additive manufacturing (FDM) using a 3D printer (Stella, Curitiba-PR, Brazil). It was used a PLA filament (Movitech) with $1.75 \mathrm{~mm}$ of diameter. A photograph of one 3D printed PLA scaffold is showed in Figure 1. 
Figure 1 - PLA scaffold obtained by additive manufacturing (FDM).

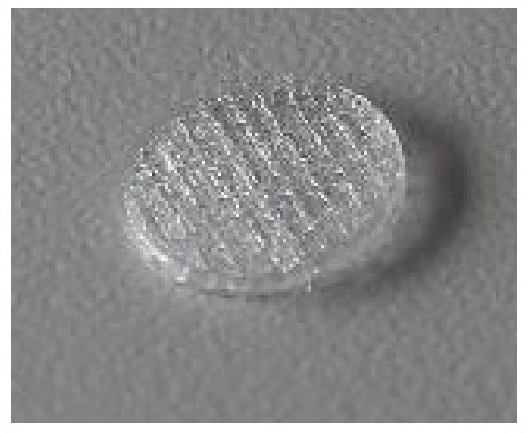

Source: Prepared by author.

\section{MODIFICATION BY OXYGEN PLASMA}

The system consists of a stainless-steel reactor $\left(\sim 5.2 \times 10^{-3} \mathrm{~m}^{3}\right)$ containing two parallel circular electrodes of $11.9 \mathrm{~cm}$ in diameter, separated by $5 \mathrm{~cm}$. The system pressure is reduced with the aid of a rotating mechanical pump (Edwards E2M18) being monitored by a Pirani type APGX sensor positioned on the upper flange of the reactor. Gases from cylinders are introduced through a stainless-steel manifold coupled to polyamide hoses, through needle-type valves (Edwards model LV-10K) for flow control. A Tokyo HyPower RF-300 Radio Frequency (RF) source (13.56 MHz, 0-300 W) coupled to a Tokyo Hy-Power MB-300 impedance hunter provides electrical signal for plasma ignition. A GBS Elektronik RUP6 20 source that generates rectangular negative voltage pulses up to $20 \mathrm{kV}$ in amplitude and up to $3 \mathrm{kHz}$ also makes up the system. This device allows control the connected pulse width between 1 and $100 \mu$ s. A Tektronix Model TDS 2014 digital four-channel oscilloscope is used to adjust the bias signal parameters. A potentiometer for controlling the sample holder resistive heating and an adjustable home voltage source (0-1200 V) for generating direct voltage bias signals are also used. Parameters - Plasma Ablation Chemical Composition Oxygen only. Plasma Excitation Signal Lower Electrode Ground Reactor Walls, 0.5 min times; 1 min; 5 minutes; 10 minutes and 20 minutes. RF Power 50 W 25 - Experimental apparatus used in film depositions. 50 Watts power was used at a pressure of $2.5 \times 10^{-2}$ Torr with a background pressure of $0.905 \times 10^{-2}$ Torr.

\section{Physical-Chemical Characterization \\ CONTACT ANGLE}

Contact angle measurements were performed in a Rami-Hart 100-00 goniometer with temperature and humidity controlled environment. Five water drops were deposited in different positions of the sample. For each drop, 20 measurements of contact angle were made, totalizing 100 values.

\section{Atomic Force Microscopy (AFM)}

Measurements were done by using a Park Systems manufacturer equipment, NX-10 model, and the operation mode was intermittent contact (tapping). The tip used was the NCHR model from the Nanosensors manufacturer, with a constant force of $42 \mathrm{~N} / \mathrm{m}$ and a resonance frequency of $320 \mathrm{KHz}$. A way to measure the surface roughness, namely root mean square roughness (Rq). Rq is the root mean square average of height deviation taken from the mean image data plane.

\section{FOURIER TRANSFORM INFRARED SPECTROSCOPY (FTIR)}

Transmittance spectra $\left(4 \mathrm{~cm}^{-1}\right.$ resolution, wavenumber range $\left.400-4000 \mathrm{~cm}^{-1}\right)$ were obtained by using 
a VERTEX 70 Absorption spectrophotometer, BRUKER, with an ATR accessory and a DLaTGS detector.

\section{Cell Viability and PROLIfERATION (IN Vitro TEST)}

Cell viability and proliferation, using osteo - 1 lineage (obtained directly from mice to start the strain), were evaluated using the fluorescence detection method of Resazurin sodium salt (Sigma - Aldrich) reduction by mitochondrial enzymes of viable cells. First, all scaffolds were sterilized under UV light for 1 hour (30 min each side) before cell assay. Second, using a 24-well flatbed cell culture plate ( diameter: $16.25 \mathrm{~mm}$; height: $17.3 \mathrm{~mm}$ and maximum volume: $3.5 \mathrm{~mL}$ each well was filled with sterilized PLA scaffolds (functionalized by oxygen plasma) and $1 \times 10^{5}$ cells per well were seeded and grown in culture medium DMEM with $10 \%$ of fetal bovine serum for 24 hours to adhere to scaffolds. After adhesion the medium was removed, and cells were incubated in presence of resazurin solution $10 \%(\mathrm{v} / \mathrm{v})$ in culture medium for 4 hours. After incubation the resazurin solution was transferred to a 96 well plate and the fluorescence was detected in a reader plate (570 $\mathrm{nm}$ excitation and $590 \mathrm{~nm}$ emission). DMEM medium was added and cells were maintained in culture for another 48 hours. The procedure with resazurin incubation was repeated and fluorescence detected. The experiment was performed in duplicate and to fixation process it was used paraformaldehyde $4 \%$.

\section{RESULTS AND DISCUSSION}

\section{Contact Angle}

The wettability of the samples was determined by the sessile drop method, using the scaffold samples of PLA functionalized by the oxygen plasma. The results corresponded to the arithmetic mean and to the standard deviation, as shown in Figure 2.

Figure 2 - Water contact angles on 3D printed PLA scaffolds modified by plasma at different $\mathrm{O}_{2}$ action times: $0 \mathrm{~min}, 0.5 \mathrm{~min}, 5 \mathrm{~min}, 10 \mathrm{~min}$ and $20 \mathrm{~min}$, where $0 \mathrm{~min}$ represents the untreated PLA scaffold.

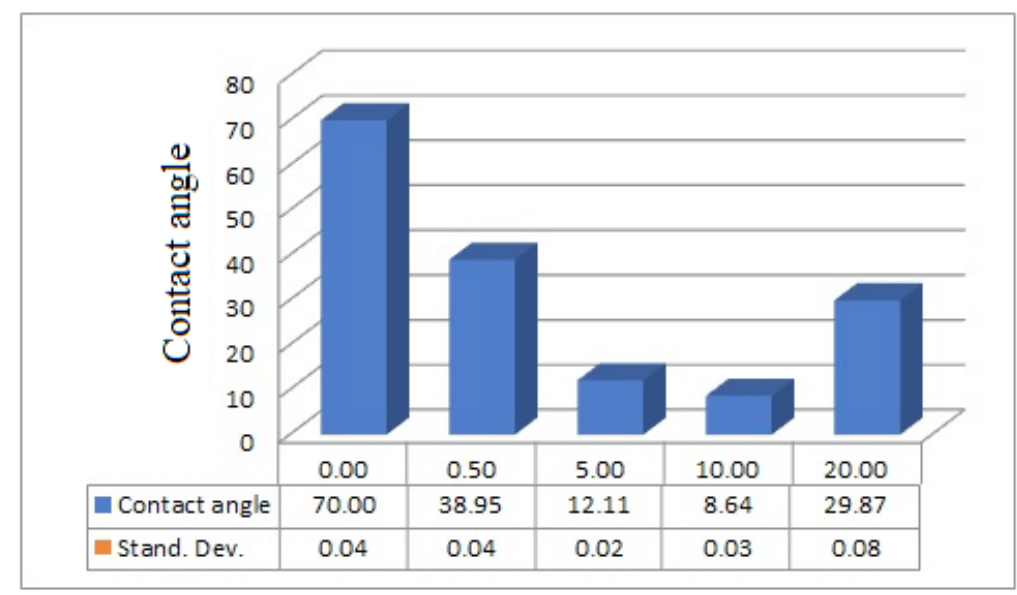

Source: Prepared by author.

The non-functionalized PLA scaffold has a contact angle of $70^{\circ}$. Compared with those in the literature, the results corroborate that the surface becomes reactive when undergoing ablation in a shorter working time, as demonstrated at the contact angles at $0.5 \mathrm{~min} ; 5 \mathrm{~min}$ and by increasing the working time to 10 minutes. However, it was found that this period is enough for the plasma to activate the entire surface of the exposed PLA, giving the lowest contact angle $\left(8.64^{\circ} \pm 0.03^{\circ}\right)$ and, therefore, greater hydrophilicity. When this period was extended to 20 minutes, a decrease in this active surface was observed, since the 
excessive working time of the oxygen plasma provokes the recombination of the species generate by plasma, impairing the hydrophilicity (Lai et al.,2015).

\section{ATOMIC FORCE MICROSCOPY}

The morphology of the scaffold surface was modified during the exposure to the etching in the plasma reactor. These morphologies at the different times are presented in Figure 3. The roughness formed on the surface has height, width and thickness, which are modified over the measured time intervals.

Figure 3 - AFM images of 3D printed PLA scaffolds. The scaffolds were modified by $\mathrm{O}_{2}$ plasma at different times: $0.5 \mathrm{~min}, 5 \mathrm{~min}, 10 \mathrm{~min}$ and $20 \mathrm{~min}$.

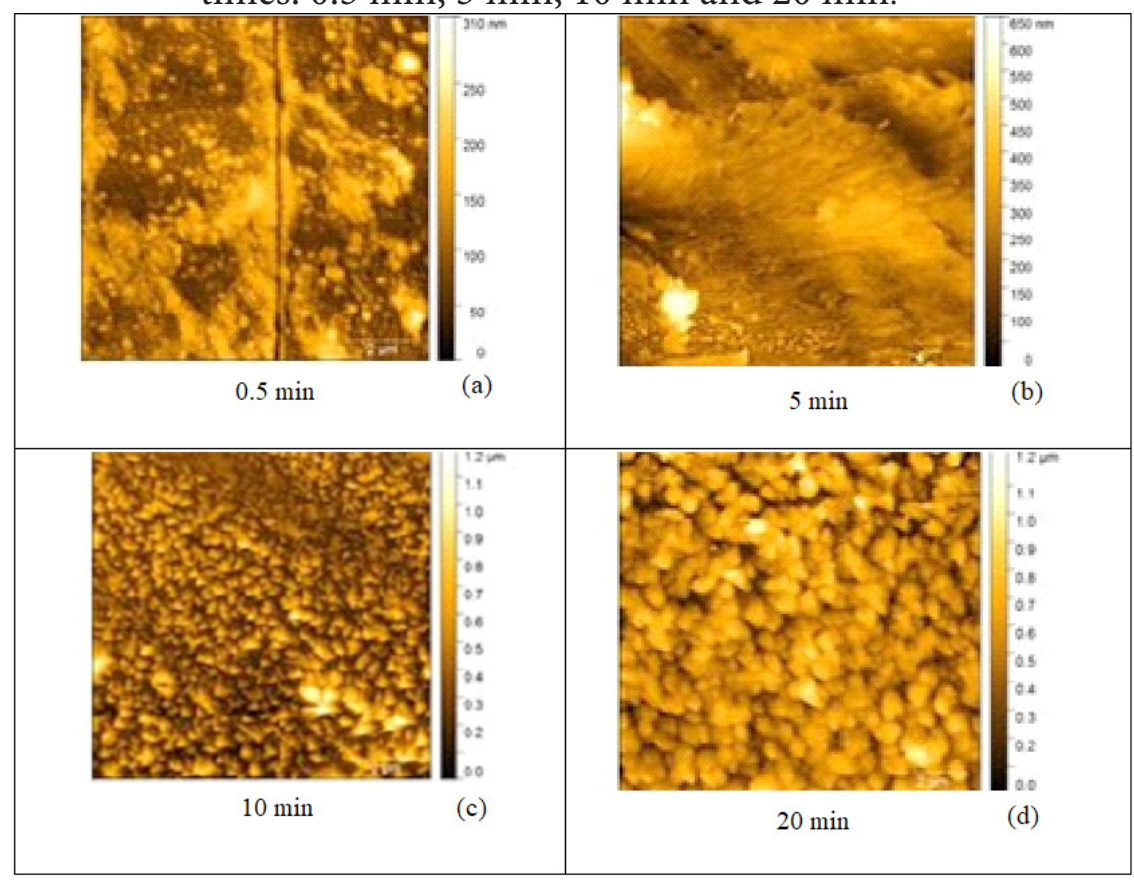

Source: Prepared by author.

It can be observed that higher plasma time exposures accounted for an increase in the roughness. This increase was directly proportional to the time of the scaffold submitted to the plasma. The plasma etching promotes the incorporation of functional groups as well as the etching of surface. This etching can modify significantly the topography and the roughness (Table 1). The roughness is caused by plasma in the nanometer dimension, as it was observed by Lai (2015). By functionalizing in the nanometer dimension, the scaffold surface became more reactive (see figure 3 ).

Table 1 - Surface roughness values of the 3D printed PLA scaffolds at different $\mathrm{O}_{2}$ plasma modification times.

\begin{tabular}{l|l|l|l|l|l}
\hline Plasma treatment (min) & 0 & 0.5 & 5 & 10 & 20 \\
\hline Surface Roughness (nm) & 92 & 100 & 500 & 1000 & 800 \\
\hline
\end{tabular}

Source: Prepared by author.

It was obtained a $92 \mathrm{~nm}$ roughness for the scaffold that did not receive the plasma treatment. The 
same value was reported by Jaidev and Chatterjee (2019). When scaffolds receiving the oxygen plasma treatment, the roughness increased to $100 \mathrm{~nm}, 500 \mathrm{~nm}$ and $1000 \mathrm{~nm}$ for times of $0.5 ; 5$ and 10 minutes, respectively. With this increased roughness, the hydrophilicity behaved in an inverse and progressive way, peaking at 10 minutes with $8.64^{\circ} \pm 0.30^{\circ}$ contact angle. Lai (2015) state that in their study the decrease in roughness leads to increased hydrophilicity. In contrast, the results at 20 minutes of ablation showed a disassembly of the surface, with decrease of roughness and increase of contact angle to $29.87^{\circ} \pm 0.08^{\circ}$ (see figure 2), with consequent decrease in hydrophilicity.

\section{INFRARED SPECTROSCOPY WITH FOURRIER TRANSFORM (FTIR)}

The FTIR spectra of the unmodified PLA scaffolds (0 min) and at different times of action of the oxygen plasma are shown in figure 4 . These show the following oxygen related bands: the $\mathrm{C}=\mathrm{O}$ stretch of the ester group at $1740 \mathrm{~cm}^{-1}$, angular deformations of $\mathrm{COH}$ at $1452 \mathrm{~cm}^{-1}$ and $1363 \mathrm{~cm}^{-1}$, asymmetric axial deformations of the ester group (OCC) at $1180 \mathrm{~cm}^{-1}$ and $1080 \mathrm{~cm}^{-1}$, similar other results (MATOS et al., 2019).

Figure 4 - Fourier Transform Infrared spectra of the PLA scaffolds at different times of $\mathrm{O}_{2}$ plasma action, where 0 min represented the untreated scaffold.

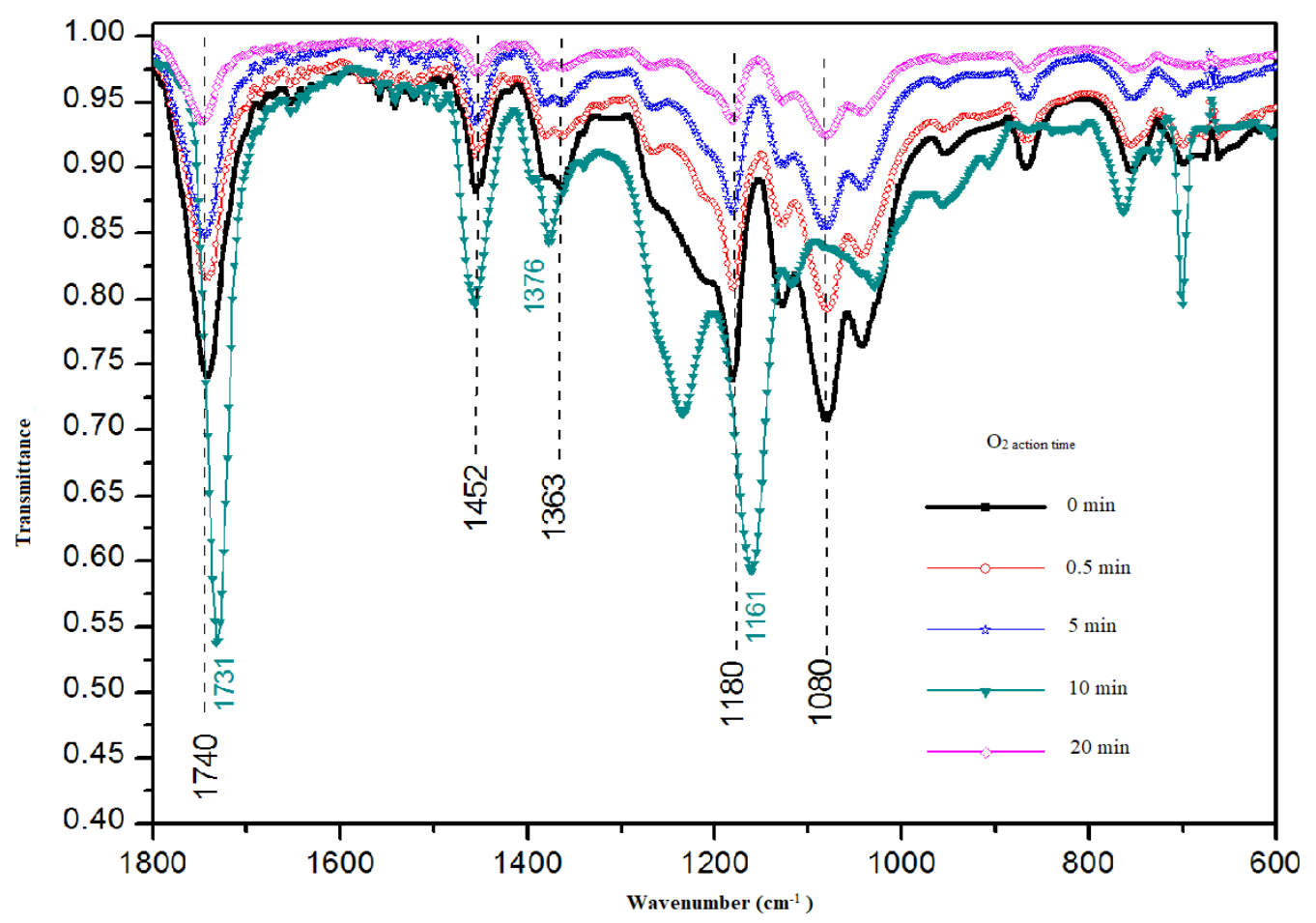

Source: Prepared by author.

The spectra showed a decrease in the intensity of these carbon-oxygen bonds $(\mathrm{C}-\mathrm{O})$ with increasing plasma action time, similar to that described by Lai (2006), except for the sample with 10 min of $\mathrm{O}_{2}$. Once the time is increased to $20 \mathrm{~min}$, the greatest decrease in the intensity of these bands is noted, suggesting a loss of $\mathrm{C}-\mathrm{O}$ bonds. These losses can be explained by breaks of these bonds with subsequent recombination of radicals without the formation of oxygenated species on the surface (INAGAKI et al., 2002).

In the case of the PLA scaffold with 10 min of treatment, increases in the peak intensities and 
small displacements of different C-O bands were observed, evidencing an increase in the quantity of oxygenated species, thus suggesting the oxidation of the material surface by action of the oxygen plasma (Jordá-Vilaplana et al., 2014). Thus, the raise of $\mathrm{C}=\mathrm{O}$ type bonds on the polymer surface increases PLA hydrophilicity (LAI et al., 2006). This hydrophilicity increase has already been observed in our previous results with the greatest decrease of the contact angle and increase in surface roughness of the PLA scaffolds at $10 \mathrm{~min}$.

\section{CELL VIABILITY AND PROLIFERATION}

The physiological behavior and biocompatibility of the biomaterial consists in: not presenting cytoxicity; not being allergenic; not being carcinogenic and not causing any damage to the host site over time (WANG et al., 2013). The in vitro test aims to measure cellular responses in the presence of the biomaterial. This, in turn, offers a level of safety due to reactions caused by the biomaterial in clinical situations. The physiological processes depend on the health of the host, the biomaterial surface and its physical-chemical process (WANG et al., 2013).

The use of osteo-1 lineage cells is because the scaffold may have potential for bone regeneration. Resazurin was used to evaluate cell viability and proliferation. Resazurin (blue and nonfluorescent) is reduced to resorufin (pink and highly fluorescent) which is further reduced to hydroresorufin (uncoloured and nonfluorescent). This dye changes its pigmentation in the medium due to live cell activity, is accepted as a standard test for cell viability and proliferation (BRIEN et al., 2000). The fluorescence results are showed in Figure 5. It is noted that all materials present cell viability, by the fluorescence values, indicating that the PLA scaffolds don't have cytotoxic effects. These results agree with Queiroz et al., they verified that PLA membranes did not present cytotoxicity in vitro and also promoted proliferation of osteoblasts (QUEIROZ et al., 2019).

The proliferation was estimated by the fluorescence difference between the $1^{\text {st }}$ and $3^{\text {rd }}$ day of each group. For the control group, the fluorescence $(\mathrm{F})$ beginning in $6.8 \times 10^{7}$ and increase up to $55 \times 10^{7}(\mathrm{p}=0.0114)$, in the 0.5 min group, F beginning in $5.8 \times 10^{7}$ and increase up to $46 \times 10^{7}(\mathrm{p}=0.0156)$, in the 5 min group $\mathrm{F}$ started at $17 \times 10^{7}$ and reach $49 \times 10^{7}(\mathrm{p}=0,0898)$, in the $10 \mathrm{~min}$ group F started at $13 \times 10^{7}$ and increase up to $54 \times 10^{7}(\mathrm{p}=0,0670)$ and in the 20 min group F beginning in $10 \times 10^{7}$ and reach $67 \times 10^{7}(\mathrm{p}=0,0194)$. It was found that the proliferation in treated scaffolds with 5 and 10 minutes don't have statistically significant difference (with $95 \%$ of confidence level) and an improvement in proliferation for the untreated scaffold (control) and for the treated scaffolds with 0.5 and 20 minutes. These last groups presented contact angles greater than of $29^{\circ}$, indicating that osteo- 1 lineage cells in this case prefer the less hydrophilic materials to proliferate.

To analyze the method efficiency was used the $3^{\text {rd }}$ day fluorescence values for comparing the control with each group. The obtained probability values were 0.3310 (0.5 $\mathrm{min}) ; 0.6190$ (5 $\mathrm{min}) ; 0.9416(10 \mathrm{~min})$ and 0.3313 (20 $\mathrm{min})$, indicating that not statistically significant difference were obtained in proliferation with the oxygen plasma modification for this osteoblastic cells.

It was noticed, as in the study by Gregor (2017), that the ablation of PLA scaffold surface printed by additive manufacturing proved to be easy, versatile and with an excellent cost-benefit relation. The use of substances and processes of easy access, low cost and eco-friendly (MATOS et al.,2019) for the optimization of roughness, hydrophilicity, viability and cell proliferation is recommended. 
Figure 5 - Viability and proliferation of 3D printed PLA scaffolds. It was represented the untreated PLA scaffold ( $0 \mathrm{~min}$-control) and the different times of $\mathrm{O}_{2}$ plasma action: $0.5 \mathrm{~min}, 5 \mathrm{~min}, 10 \mathrm{~min}$ and $20 \mathrm{~min}$.

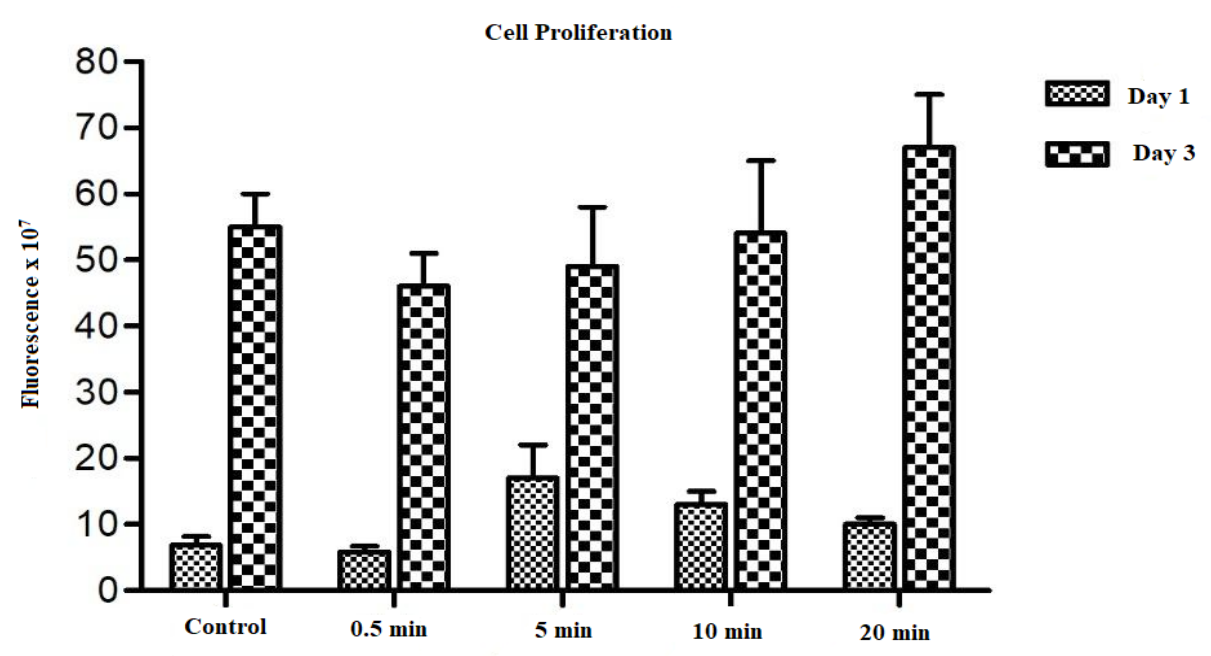

Source: Prepared by author.

\section{Conclusions}

The oxygen plasma modification in the surface of 3D printed PLA scaffolds is an easy and versatile method that allowed increasing the PLA hydrophilicity and surface roughness. The better result was obtained by using a plasma exposure time of 10 minutes. Although the surface modifications were effective and the PLA scaffolds were not cytotoxic, there were no improvements in the proliferation process with the studied osteo-1 lineage cells. Therefore, to validate the method future studies will be done with other types of cells.

\section{ACKNowledgements}

The authors are grateful for the support provided by the universities involved in this research: Biopolymers and Biomaterials Research Group - BIOPOLMAT. University of Araraquara - UNIARA; Department of Chemistry, Center for Exact Sciences and Technology. Federal University of São Carlos, UFSCAR; Plasma and Materials Group, Sorocaba Institute of Science and Technology. Paulista State University - UNESP. Sorocaba; University of Franca - UNIFRAN.

\section{REFERENCES}

BANDYOPADHYAY, A; BOSE, S. “3D printing of biomaterials”, Sumandas. MRs Bulletin, v.40, p.108112. February, 2015.

BOSE, S; ROY,M; BANDYOPADHYAY, A. "Recent advances in bone tissue engineering scaffolds” Trends in biotechnology, v.30, n. 10, p. 546-554, 2012.

BRAGHIROLLI, D. I. - Produção de scaffolds contendo células tronco para uso na engenharia de 
Polylactic acid scaffolds obtained by $3 d$...

tecidos através da associação das técnicas electrospinning e bio-eletrosparying. Julho de $2012.94 \mathrm{f}$. Dissertação (Mestrado em Ciências dos Materiais) - Universidade Federal do Rio Grande do Sul, Porto Alegre - RS, 2014.

BRIEN, J, O; WILSON, I; ORTON, T; POGNAN, Ë. Investigation of the Alamar Blue (resazurin) fluorescent dye for the assessment of mammalian cell cytotoxicity. European Journal of Biochemistry, v. 267, p.5421-5426, 2000.

CHEN, C. B. LIANG, D. Lu, A. OGINO, X. WANG, M. NAGATSU, “Amino group introduction onto multiwall carbon nanotubes by NH3/Ar plasma treatment”, Carbon. v. 48, [S. 1.], p.939-948, 2010.

GREGOR, A; FILOVÁ, E; NOVÁK, M; KRONEK, J; CHLUP, H; BUZGO, M; BLAHNOVÁ, V; LUKÁSOVÁ, V; BARTOS, M; NECAS, A; HOSEK, J. Designing of PLA scaffolds for bone tissue replacement fabricated by ordinary commercial 3D printer. Journal of Biological Engineering, v.11, n.1, p.1-21, 2017.

INAGAKI, N.; NARUSHIMA, K.; TSUTSUI, Y.; OHYAMA, Y. Surface modification and degradation of poly(lactic acid) films by Ar-plasma. Journal of Adhesion Science and Technology, v. 16, n. 8, p. 1041-1054, 2002.

JAIDEV, L, R; CHARTTERJEE, K. Surface functionalization of 3D printed polymer scaffolds to augment stem cell response. Materials and Design, v.161, p.44-54, 2019.

JORDÁ-VILAPLANA, A; FOMBUENA, V; GARCÍA-GARCÍA, D; SAMPER, M.D; SÁNCHEZ-NÁCHER, L. Surface modification of polylactic acid (PLA) by air atmospheric plasma treatment. European Polymer Journal, v. 58, p. 23-33, 2014.

KODAMA, H. "Automatic method for fabricating a three-dimensional plastic model with photohardening polymer” Review of Scientific Instruments, v.52, n. 11, p. 1770-73, 1981.

LAI, Jiangnan; SUNDERLAND, Bob; XUE, Jianming; YAN, Sha; ZHAO, Weijiang; FOLKARD, Melvyn; MICHAEL, Barry D.; WANG, Yugang. Study on hydrophilicity of polymer surfaces improved by plasma treatment. Applied Surface Science, v. 252, n. 10, p. 3375-3379, 2006.

LI, J; He, L; ZHOU, C; ZHOU, Y; BAI, Y; LEE, F. Y; MAO, J. J. 3D printing for regenerative medicine: From bench to bedside. MRS Bulletin, v.40, n.2, p.145-153, 2015.

LU, L; MIKOS, A, G. The importance of new processing techniques in tissue engineering. MRS Bulletin, v. 21, n. 11, p. 28-32, Nov, 1996.

MATOS, B. D. M; ROCHA, V; DA SILVA, E. J; MORO, F. H; BOTTENE, A. C; RIBEIRO, C. A; DOS SANTOS DIAS, D; ANTONIO, S. G; DO AMARAL, A. C; CRUZ, S. A; DE OLIVEIRA BARUD, H. G; SILVA BARUD, H, da. Evaluation of commercially available polylactic acid (PLA) filaments for 3D printing applications. Journal of Thermal Analysis and Calorimetry, v.137, n.2, p.555-562, 2019. 
MORENT, R; DE GEYTER, N; DESMET, T; DUBRUEL, P; LEYS, C. Plasma surface modification of biodegradable polymers: A review. Plasma Processes and Polymers, v.8, n.3, p. 171-190. 2011.

NGO, T, D; KASHANI, A; IMBALZANO, G; NGUYEN, Kate T. Q; HUI, D. Additive manufacturing (3D printing): A review of materials, methods, applications and challenges. Composites Part B: Engineering, v. 143, n.2 p.172-196, 2018.

QUEIROZ, T, S, D; PRADO, R, F; APARECIDA, I; BRITO, W, D; OLIVEIRA, L, D, D; MAROTTA, L; VASCONCELLOS, R, D; CAMARGO, E, A. Cytotoxicity and Genotoxicity of PLA and PCL Membranes on Osteoblasts. Acta Scientific Dental Sciences, v. 3, n. 4, p.55-59, 2019.

WANG, M; CHENG, X; ZHU, W; HOLMES, B; KEIDAR, M; ZHANG, L, G. Design of Biomimetic and Bioactive Cold Plasma-Modified Nanostructured Scaffolds for Enhanced Osteogenic Differentiation of Bone Marrow-Derived Mesenchymal Stem Cells. Tissue Engineering Part A, v. 20, n.5-6, p.1060-1071, 2013.

YEH, C, H; CHEN, Y, W; SHIE,M-Y; FANG, H-Y. "Poly (Dopamine) - Assisted Immobilization of xu Duan on 3D printed poly (lactic acid) scaffolds to up- regulate osteogenic and angiogenic markers of bone marrow stem cells. Materials, n.8, p.4299-4315, 2015.

ZEIN, I; HUTMACHER, D, W; TAN, K, C; TEOH, S, H. Fused deposition modeling of novel scaffold architectures for tissue engineering applications. Biomaterials, v.23, n.4, p.1169-1185, 2002. 